\title{
PENERAPAN TEKNOLOGI KULTUR JARINGAN BAGI PETANI ANGGREK DI DESA BERJO, KARANGANYAR
}

\author{
Solichatun, Ari Pitoyo, Nita Etikawati, Elisa Herawati, Tanjung Ardo \\ Program Studi Biologi, FMIPA, Universitas Sebelas Maret
}

Email: solichatun@staff.unc.ac.id; aripitoyo@staff.uns.ac.id; netikawati@yahoo.com; elisahera@staff.uns.ac.id; tanjungardo@staff.uns.ac.id

\begin{abstract}
Abstrak
Berjo adalah sebuah desa di lereng Gunung Lawu, tepatnya di Kecamatan Ngargoyoso, Kabupaten Karanganyar, Jawa Tengah. Pembudidaya anggrek di daerah tersebut telah memulai usaha pembesaran anggrek sejak empat tahun yang lalu. Pengusaha mikro ini mampu menghasilkan dan menjual produk berupa tanaman anggrek remaja dan dewasa meskipun dalam kapasitas terbatas. Upaya meningkatkan kapasitas produksi terkendala oleh kemampuan memperoleh bibit secara mandiri. Kebutuhan bibit masih mengandalkan pasokan dari luar.

Program kemitraan masyarakat ini dirancang untuk memberikan solusi permasalahan mitra melalui penerapan kultur jaringan. Biji anggrek sulit dikecambahkan karena tidak memiliki cadangan makanan bagi embrio untuk tumbuh dan berkembang. Teknik kultur jaringan adalah cara paling efisien mengecambahkan biji anggrek dengan memberi asupan nutrisi secara aseptis.

Kegiatan pengabdian meliputi aktivitas edukasi (transfer knowledge), instalasi peralatan dengan penyediaan enkas dan autoklaf sederhana, serta pendampingan praktek kultur jaringan dengan teknik aseptik untuk memperoleh bibit anggrek.

Hasil kegiatan yang telah diperoleh yaitu petani sudah mampu membuat media kultur jaringan secara mandiri; melakukan kegiatan penanaman biji anggrek di dalam botol kultur dengan teknik aseptik dengan bantuan enkas. Enkas adalah suatu ruang penanaman steril yang membatasi udara keluar masuk. Biji anggrek yang dikulturkan sudah berhasil tumbuh meskipun masih ada kotaminasi pada beberapa botol kultur.
\end{abstract}

Kata Kunci: kultur jaringan, anggrek, perkecambahan, pembibitan

\section{PENDAHULUAN}

Anggrek adalah komoditi andalan sektor florikultur atau tanaman hias. Data Badan Pusat Statistik (BPS) selalu menempatkan tanaman ini dalam lima besar tanaman prioritas yang selalu terpantau angka produksi, nilai, hingga ekspor impornya. Volume total produksi nasional yang mencapai angka 3.619.174 tangkai lebih terkonsentrasi di Pulau Jawa terutama Jawa Barat, Jawa Timur, dan Banten (BPS, 2019). Di daerahdaerah tersebut produksi anggrek terpusat di daerah yang memiliki kondisi lingkungan yang sejuk dan cahaya berlimpah. Di kawasan pegunungan di daerah Jawa Tengah, masih jarang dijumpai pusatpusat produksi anggrek.

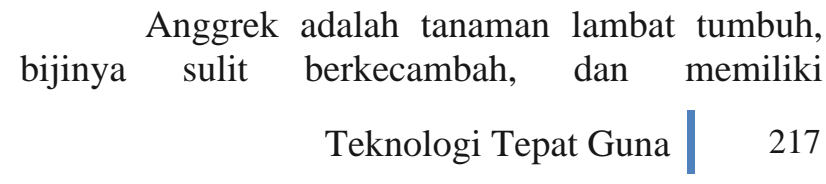


ketergantungan yang cukup tinggi terhadap simbion untuk perkecambahan biji maupun penyerbukannya (Fay \& Chase, 2009; Rasmussen \& Rasmussen, 2007). Dalam alur produksi atau budidaya anggrek, untuk setiap satu siklusnya mulai dari perkecambahan hingga dihasilkan biji lagi, membutuhkan dasar pengetahuan dan keterampilan yang cukup terhadap teknologi perbanyakan tanaman. Setiap langkah dalam produksi anggrek sering kali membutuhkan input teknologi. Input teknologi yang sudah diketahui efektif dalam budidaya anggrek adalah teknologi kultur in vitro atau masyarakat awam umunya menyebut kultur jaringan (tissue culture). Kultur in vitro dapat digunakan untuk perbanyakan anggrek (mikropropagasi) atau untuk mengecambahkan biji anggrek.

Anggrek dapat diperbanyak secara generatif melalui pembentukan biji. Seperti umumnya tumbuhan berbunga, biji anggrek diperoleh melalui serangkaian tahap reproduksi yang diawali dari penyerbukan, pembentukan buah, peleburan gamet jantan dan betina dan diakhiri dengan terbentuknya biji (Zhang et al. 2018). Setiap satu kapsul atau buah anggrek mengandung ribuan bahkan ratusan ribu biji. Meskipun demikian, biji anggrek sulit dikecambahkan karena endosperm yang seharusnya memberikan asupan nutrisi bagi embrio saat perkecambahan, tidak terbentuk pada biji anggrek. Di habitat tumbuhnya, biji anggrek hanya mampu berkecambah saat fungi(cendawan) menginfeksi embrio melalui suspensor (Huang 2014; Rasmussen \& Rasmussen, 2009).

Kesulitan perbanyakan anggrek masih menjadi hambatan utama produksi massal tanaman ini untuk kebutuhan industri (Yam \& Arditti, 2009; Nuraini et al., 2011). Kesulitan perkecambahan biji anggrek terpecahkan oleh upaya perkecambahan secara in vitro, yaitu perkecambahan biji pada suatu media kaya nutrisi dalam lingkungan steril. Perkecambahan tipe ini juga sering diistilahkan dengan perkecambahan biji anggrek asimbiotik (non-simbiotik). Perkembangan selanjutnya, teknik in vitro juga digunakan untuk perbanyakan anggrek melalui kultur jaringan atau perbanyakan somatik. Perbanyakan melalui kultur in vitro sekaligus dapat digunakan untuk mempertahankan genotip unggul suatu jenis anggrek, dimana sifat ini ada kemungkinan berubah karena perkawinan.

Pabongan Orchid adalah nama unit usaha mikro berskala rumah tangga yang mengkhususkan diri pada budidaya anggrek. Secara fisik, Pabongan Orchid adalah nursery atau tempat pemeliharaan anggrek yang merangkum aktivitas pembesaran, pembungaan, dan pemasaran anggrek khususnya hasil silangan spesies lokal. Pabongan sendiri adalah nama dusun yang berlokasi di Desa Berjo, Kecamatan Ngargoyoso, Kabupaten Karanganyar, Propinsi Jawa Tengah. Secara geografis lokasi ini berada pada kawasan Gunung Lawu pada ketinggian antara 840 - 1540, sehingga memiliki iklim pegunungan yang sejuk dengan kisaran suhu rata-rata $21^{\circ} \mathrm{C}$ (www.karanganyarkab.go.id).

Pabongan Orchid secara resmi telah memulai aktivitas budidaya anggrek sejak empat tahun yang lalu. Meskipun demikian, inisiasi nursery ini sudah dirintis jauh hari sebelumnya yaitu sekitar tahun 2010, ketika pemilik usaha ini masih menganggapnya sebatas hobi pengisi waktu luang. Saat ini, meskipun belum memiliki sistem pengelolaan yang baku, Pabongan Orchid sudah melibatkan beberapa orang dengan definisi tugas yang jelas. Unit usaha ini dapat dibagi menjadi dua bagian besar yaitu unit produksi dan unit pemasaran. Unit produksi bertugas memastikan tersedianya produk anggrek layak jual yang meliputi aktivitas aklimatisasi bibit dari dalam botol ke media tanam, pembesaran, dan pembungaan anggrek. Unit pemasaran, berperan untuk memasarkan anggrek layak mutu kepada konsumen. Berbekal kapasitas nursery dan cara pengelolaan seperti ini, Pabongan Orchid sudah mampu memperoleh laba bersih 4-6 juta rupiah per bulan.

Di Pabongan Nursery terdapat ratusan tanaman anggrek remaja dan dewasa, dari berbagai jenis. Tanaman anggrek produk pembesaran Pabongan Orchid cukup diminati karena kejeliannya memilih bibit hasil silangan anggrek spesies lokal. Kondisi lingkungan harian di daerah pegunungan juga sangat mendukung usaha ini karena suhu rata-rata siang hari di kisaran $24-27$ ${ }^{\circ} \mathrm{C}$ sangat ideal bagian anggrek khususnya jenisjenis anggrek epifit lokal. Keberlangsungan usaha ke depan diprediksi masih sangat terbuka, selain

$$
\text { Teknologi Tepat Guna }
$$


karena harga anggrek yang relatif stabil, juga karena kemudahan memasarkannya baik secara konvensional maupun lewat penjualan online (daring). Selain untuk tujuan komersialisasi, Pabongan Orchid juga diminati oleh pengunjung khususnya bagi mereka yang memiliki minat besar untuk belajar tentang budidaya anggrek.

\section{Permasalahan:}

Permasalahan utama mitra pada nursery ini adalah belum adanya kemandirian bibit anggrek. Untuk meningkatkan kapasitas dan kualitas produksi; pemenuhan bibit secara mandiri sangat diperlukan. Ketergantungan terhadap pasokan dari luar memiliki konsekwensi pada pembengkakan biaya produksi maupun fluktuasi mutu produk. Menariknya, mitra sebenarnya memiliki bekal yang cukup untuk mengusahakan kemandirian bibit karena memiliki cukup banyak koleksi anggrek untuk dapat dijadikan tetua persilangan. Permasalahannya adalah, mitra tidak memiliki cukup pengetahuan dan teknologi untuk mengecambahkan biji anggrek yang terbentuk dari hasil keberhasilan persilangan. Satu kapsul buah anggrek seringkali mengandung ribuan bahkan ratusan ribu biji. Biji anggrek ini seharusnya bisa dikecambahkan pada media yang sesuai untuk dapat berkembang menjadi protocorm like bodies (plb) terbentuk tunas dan pada akhrnya terbentuk planlet (tanaman kecil). Planlet kemudian diaklimatisasi agar mamou tunbuh pada media di lapang. Ketidakmampuan mitra mengecambahkan biji anggrek menjadikan kendala utama memperoleh bibit secara cepat dalam jumlah besar. Hal ini akan diupayakan untuk dapat diatasi dengan peningkatan pengetahuan dan keterampilan mitra dalam teknik kultur in vitro anggrek.

\section{Tujuan:}

Kegiatan pengabdian ini bertujuan untuk memberikan bantuan dan pendampingan teknis ketrampilan kultur in vitro dengan peralatan sederhana sehingga pembudidaya dapat melakukan pengkulturan biji anggrek secara mandiri dan pada akhirnya mencapai kemandiriain penyediaan bibit.

\section{METODE}

Kegiatan pengabdian dilaksanakan pada beberapa tahap yang meliputi edukasi mitra tentang teknologi dan teknik kultur in vitro khususnya dalam perbanyakan anggrek dan pendampingan praktek teknik aseptik serta penanaman biji pada media kultur.

\section{Edukasi Mitra terhadap teknologi yang akan diintroduksikan}

Sebagai mana uraian sebelumnya, kegiatan pengabdian yang akan dilaksanakan adalah penerapan teknologi kultur in vitro untuk mengatasi permasalahan pemenuhan stok bibit anggrek. Tim pengabdi merasa perlu membekali mitra dengan dasar-dasar keilmuan kultur in vitro yang meliputi: metode sterilisasi, pemilihan dan formulasi media, teknik pengambilan sampel dan penanaman, standard operasional tiap instrumen, dan prosedur keamanan tentang kultur in vitro. Metode edukasi dilakukan melalui diskusi langsung dengan mitra dan pembuatan petunjuk operasional baku dalam bentuk terdokumentasi.

\section{Pendampingan praktek kultur in vitro anggrek}

Setelah bahan dan alat yang dibutuhkan telah terpenuhi dan dipastikan berfungsi dengan baik, maka dilakukan pendampingan dalam penerapan teknologi kultur in vitro pada mitra. Proses pendampingan yang dimaksud meliputi tahap: pemilihan bahan atau material tanaman; pemilihan dan pembuatan media; sterilisasi bahan tanaman, media dan peralatan; penanaman eksplan menggunakan enkas (lemari steril, pengganti laminar air flow cabinet).

\section{tanaman.}

Tahap pemilihan bahan atau material

Semua bagian tanaman selama masih memiliki jaringan yang hidup dapat digunakan sebagai material (eksplan) kultur in vitro. Jaringan dan organ yang masih muda lebih sesuai sebagai eksplan karena banyak sel yang masih atau sedang aktif membelah. Eksplan yang dipilih pada kegiatan pengabdian ini adalah biji anggrek yang merupakan produk hasil dari keberhasilan persilangan. Mitra diberikan beberapa cara dan kiat memilih kondisi buah yang tepat untuk memanen biji didalamnya.

$$
\text { Teknologi Tepat Guna }
$$


Buah yang dipilih adalah buah yang sudah masak tetapi belum pecah sehingga biji di dalamnya masih dalam kondisi steril. Mitra dibekali pengetahuan untuk mengenali ciri-ciri buah yang siap digunakan sebagai sumber biji untuk dikulturkan.

\section{Pemilihan dan pembuatan media.}

Media kultur in vitro harus memiliki kecukupan hara, mineral, hormon, dan senyawa organik yang dibutuhkan eksplan untuk tumbuh dan berkembang. Kondisi in vitro juga menuntut asupan karbon organik pada media karena terhalangnya $\mathrm{CO}_{2}$ masuk ke dalam botol. Pada tahap ini mitra diberikan pendampingan teknik pembuatan dan formulasi media yang tepat. Mitra juga diberikan kiat memilih bahan-bahan alternatif pengganti media standard yang ada di pasaran, Media standard yang ada di pasaran yang umum digunakan untuk budidaya anggrek adalah media Vacin \& Went (VW), beberap peneliti juga berhasil menggunakan media Murashige-Skoog (MS). Selain media standard, media organik juga dapat dikembangkan untuk tujuan kultur in vitro. Beberapa tambahan homogenat seperti bubur/jus pisang, tomat, touge, dan beberapa ekstrak buah telah banyak diketahui dapat menggantikan kebutuhan nutrisi standard. Penggunaan air kelapa juga dapat menggantikan hormon sintetik.

\section{peralatan.}

Sterilisasi bahan tanaman, media dan

Pendampingan terkait teknik sterilisasi dan penggunaan instrument sterilisasi sangat diperlukan. Sterilisasi bahan tanaman biasanya menggunakan alkohol maupun produk disinfektan lainnya. Konsentrasi sterilan dan lama waktu perendaman merupakan tahap yang sangat penting. Sterilisasi yang baik adalah ketika tidak didapat kontaminasi dan ekplan dapat tumbuh dan berkembang. Eksplan biji yang masih berada pada struktur buah yang belum pecah biasanya masih steril, sehingga perlakuan sterilisasihanya diperlukan pada struktur buahnya.

Sterilisasi media dan alat menggunakan autoklaf yang diatur suhu dan tekanannya. Suhu yang dibutuhkan untuk sterilisasi biasanya mencapai $121^{\circ} \mathrm{C}$, dan tekanan $1.5 \mathrm{~atm}$, selama 1 jam untuk peralatan, dan 20 menit untuk media.
Prosedur keamanan dan keselamatan kerja sangat ditekankan ke mitra berkaitan dengan pengaplikasian autoklaf mulai dari awal hingga akhir sterilisasi. Uap bertekanan tinggi perlu diwaspadai karena dapat menyebabkan luka serius pada mitra.

\section{Penanaman eksplan menggunakan enkas (lemari steril, pengganti laminar air flow cabinet/LAF).}

Prinsip kerja di laminar air flow (LAF) adalah transfer atau penanaman eksplan ke media dalam botol kultur secara steril. Laminar air flow cabinet tidak dimiliki oleh mitra dan dari segi harga sangat mahal untuk skala industri rumah tangga. Sebagai pengganti mitra disediakan enkas yaitu lemari kecil yang daoat disterilisasi untuk proses penanaman eksplan. Mitra diberikan pendampingan tentang prosedur pembersihan dan sterilisasi enkas, seperti penggunaan lampu bunsen dan penyemprotan dengan alkohol. Mitra juga disarankan untuk mencatat setiap langkah sterilisasi yang dilakukan sehingga dapat dijadikan evaluasi jika ada kontaminasi di kemudian hari. Pemeliharaan kultur dilakukan terutama terkait kebersihan ruang, suhu, dan penyinaran. Kultur idelanya dipelihara atau diinkubasi di ruang kultur (untuk skala laboratorium). Untuk skala rumah tangga, ruang kultur berupa ruang kecil yang harus selalu dijaga kebersihannya, diberi rak-rak penyimpanan botol kultur dan diberi lampu dengan tingkat pencahayaan yang cukup. Cahaya diperlukan untuk pembentukan klorofil sehingga eksplan/planlet tampak segar dan tidak pucat. Akan tetapi penyinaran berlebihan perlu diwaspadai karena suhu di dalam botol kultur biasanya lebih cepat naik. Biasanya ruangan dikondisikan pada suhu dibawah $24^{\circ} \mathrm{C}$ dengan air conditioner.

\section{HASIL DAN PEMBAHASAN}

\section{Tahap pemilihan bahan atau material tanaman}

Tahap pemilihan bahan tanaman yang akan digunakan sebagai sumber eksplan penting dikuasai oleh pelaku budidaya anggrek, karena tahap ini akan menentukan keberhasilan diperolehnya biji anggrek yang siap tanam. Buah anggrek yang paling

$$
\text { Teknologi Tepat Guna }
$$


baik digunakan untuk sumber biji adalah buah yang cukup matang, tidak terlalu muda dan juga tidak terlalu tua. Buah anggrek yang bijinya siap tebar/dikecambahkan pada media kultur adalah buah yang sudah dewasa ditandai dengan perhiasan bunya yang mulai layu dan rontok serta warna buah sedikit kuning. Mitra diberi bekal pengetahuan ciriciri buah yang mengandung biji siap tebar, dan sebagai contoh disajikan pada Gambar 1. Gambar 1 memperlihatkan buah anggrek Dendrobium spectabile yang matang. Di dalam buah tersebut terdapat ribuan atau bahkan ratusan ribu biji.

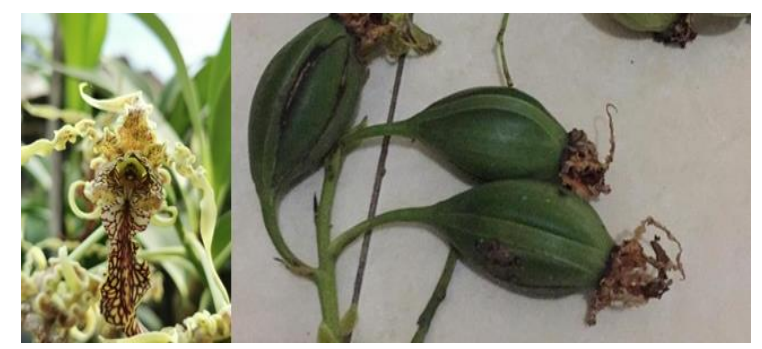

Gambar 1. Bunga anggrek Dendrobium spectabile (kiri) dan buahnya (kanan)

\section{Sterilisasi bahan tanaman, media dan peralatan}

Buah anggrek yang akan diambil bijinya untuk dikulturkan atau dikecambahkan, harus berada dalam bentuk buah belum pecah. Jika buah sudah pecah, maka biji sudah bertebaran, dan hal ini menyulitkan proses sterilisasinya. Buah yang belum pecah disterilisasi dengan mencelupkannya ke dalam larutan alkohol $70 \%$ selama beberapa menit, untuk selanjutnya dibelah menggunakan pinset steril dan diambil bijinya untuk ditebarkan dalam media kultur. Jika proses sterilisasi dan penanaman berjalan dengan baik, maka biji anggrek akan berkembang membentuk protocorm like bodies (plb).

\section{Pemilihan dan pembuatan media}

Pada kegiatan ini juga dilakukan pembuatan media untuk anggrek dengan dua jenis media, yaiu media standard Vacin \& Went (VW) dan media organik. Media VW merupakan media standard untuk anggrek dimana media telah ditentukan komposisinya (Reddy, 2019). Pada kegiatan ini mitra juga melakukan usaha pengembangan media alternatif untuk anggrek dengan komposisi bahanbahan organik yaitu ekstrak pisang, kentang, air kelapa, arang aktif dan agar sebagai pemadat. Pada media organik juga ditambahkan air kelapa karena air kelapa mengandung serupa sitokinin yang dapat mempercepat pertumbuhan eksplan. Pengembangan media umu dilakukan para pelaku budidaya untuk mengoptimalkan pertumbuhan anggrek atau jenis tanaman lain (Zahara et al., 2017). Pada kegiatan ini, hasil penggunakan media ekstrak pisang dan kentang belum memuaskan, dimana media organik tersebut mengalami kontaminasi pada hari ke-5 setelah pembuatan media. Tingkat kontaminasi media organik sangat tinggi, tercatat lebih dari $70 \%$ media yang disiapkan mengalami kontaminasi, bahkan kontaminasi terjadi sebelum media digunakan (Tabel 1). Artinya ada proses sterilisasi media organik yang belum optimal, dan hal ini perlu terus dicari penyelesaiannya. Media yag tidak mengalami kontaminasi digunakan untuk media tanam biji anggrek, tetapi hasilnya juga baik karena biji tidak berhasil tumbuh dan media kemudian mengalami kontaminasi juga.

Media alternatif perlu dikembangkan untuk mengurangi biaya produksi karena media standard VW yang harganya relatif mahal. Pengembangan media alternatif ternyata tidak mudah karena rawan kontaminasi; dan hal ini masih perlu dicarikan upaya penanggulangannya.

Tabel 1. Hasil pertumbuhan biji anggrek pada media VW dan organik

\begin{tabular}{|l|l|l|}
\hline \multirow{2}{*}{ Jenis media } & \multicolumn{2}{|c|}{ Parameter keberhasilan } \\
\cline { 2 - 3 } & \multicolumn{1}{|c|}{$\begin{array}{c}\text { Pertumbuhan biji } \\
\text { anggrek }\end{array}$} & Kontaminasi \\
\hline Media VW & berhasil tumbuh & kurang dari 10\% \\
\hline Media organik & $\begin{array}{l}\text { tidak berhasil tumbuh } \\
\text { karena mengalami } \\
\text { kontaminasi }\end{array}$ & lebih dari 70\% \\
\hline
\end{tabular}

4. Penanaman eksplan menggunakan enkas (lemari steril, pengganti laminar air flow cabinet/LAF)

Kegiatan edukasi tentang teknik aseptik, ketepatan media dan sterilisasi eksplan telah 
dilakukan. Kegiatan pendampingan dalam praktek teknik aseptik juga telah dilakukan bersama mitra kegiatan pengabdian. Hasil yang diperoleh yaitu meningkatnya penguasaan terhadap teknik aseptik kultur in vitro tumbuhan. Praktek teknik aseptik dengan bantuan lemari enkas sebagai pengganti laminar air flow cabinet (LAF) juga telag dilakukan. Penggunaan lemari enkas sangat membantu menekan kontaminasi saat menanaman biji anggrek dalam media kultur. Gambar 2 memperlihatkan saat mitra melakukan praktek penanaman biji dan subkultur protocorm like bodies menggunakan enkas. Sebelum digunakan, enkas disemprot dengan alkohol $70 \%$ di semua bagiannya. Bagian dalam enkas disemprot alkohol $70 \%$ beberap kali untuk memastikan spora bakteri maupun cendawan mati. Di dalam enkas juga digunakan lampu bunsen berupa lampu spiritus untuk menjaga kondisi steril selama proses penanaman eksplan.

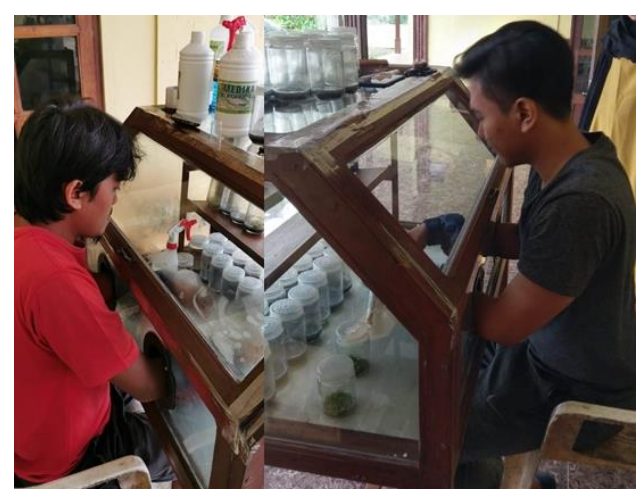

Gambar 2. Praktek penanaman biji anggrek menggunakan lemari enkas (pengganti laminar air flow cabinet) oleh mitra

Pada kegiatan ini jenis anggrek yang digunakan untuk praktek penebaran biji pada media in vitro adalah dari speies Dendrobium spectabile. Dendrobium adalah anggek yang memiliki nilai ekonomi penting, sangat beragam variasinya dan digemari oleh masyarakat karena keindahan bunganya (Tantasawat et al., 2015).

Gambar 3 memperlihatkan perkembangan biji anggrek D. spectabile pada media VW. Mulai dari biji pasca tebar (kiri atas), berkembang menjadi protocorm like bodies (kanan atas), kemudian mengalami organogenesis membentuk tunas kecil (kiri bawah), dan berkembang menjadi tanaman kecil (planlet) (kanan bawah). Planlet setelah ukurannya cukup besar siap dilakukan aklimatisasi, yaitu tahap pengadaptasikan anggrek ke media tanam pot di lapang. Kegiatan aklimatisai diawali dengan mengeluarkan planlet dari dalam botol kultur, dibersihkan akarnya, dan kemudian ditanam pada media lumut di green house atau lapang (Gambar 4).

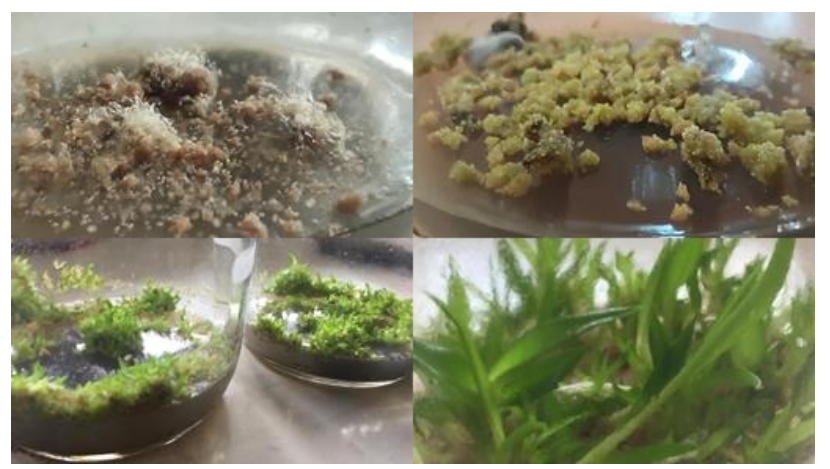

Gambar. 3. Perkembangan biji anggrek Dendrobium spectabile mulai dari biji ditebar di media VW (kiri atas), tumbuh menjadi plb (kanan atas), pertunasan (kiri bawah) dan planlet (kanan bawah).

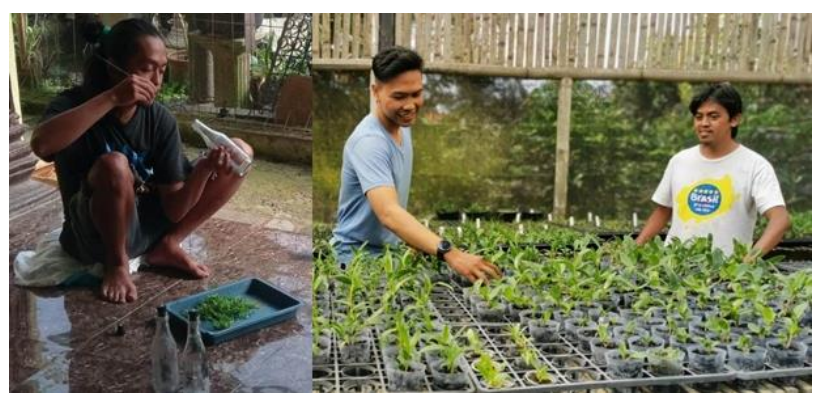

Gambar 4. Praktek aklimatisasi anggrek dari media di dalam botol ke media tanam dalam pot.

Kegiatan pendampingan teknik kultur in vitro dalam budidaya anggrek di Pabongan Nursery, di Desa Berjo, Kecamatan Ngargoyoso, Kabupaten Karanganyar telah memberikan bekal ilmu pengetahuan dan ketrampilan kepada pelaku 
budidaya. Meskipun masih ada beberapa kendala seperti dalam hal pengembangan media organik alternatif yang belum berhasil, tetapi secara umum kegiatan pendampingan praktek kulturin vitro ini telah berhasil dilakukan. Ke depannya, kegiatan pendampingan masih perlu dilakukan mengingat masih banyak jenis anggrek lain yang perlu dikembangbiakkan, dan bisa jadi permasalahan yang muncul akan berbeda.

\section{KESIMPULAN}

Edukasi dan pendampingan praktek kultur in vitro berhasil membekali ketrampilan mitra dalam teknik aseptik kultur biji anggrek. Hal ini ditunjukkan dengan keberhasilan mitra dalam praktek mengkulturkan biji anggrek pada media Vacin and Went (VW) dan berhasil tumbuh. Media Vacin and Went (VW) merupakan media standard yang sesuai untuk mengkulturan biji anggrek. Media organik dengan komposisi ekstrak pisang, kentang, air kelapa, arang aktif dan agar belum berhasil dikembangkan sebagai media alternatif kultur biji anggrek karena tingkat kontaminasi media yang sangat tinggi.

\section{UCAPAN TERIMAKASIH}

Kegiatan pengabdian kepada masyarakat ini didanai oleh dana Hibah P2M PNBP UNS tahun 2020, untuk itu kami mengucapkan terima kasih.

\section{REFERENSI}

BPS, (2019). StatistikTanamanHias Indonesia 2018. BPS Indonesia

Fay MF \& Chase MW. (2009). Orchid Biology: from Linnaeus via Darwin to the $21^{\text {st }}$ century. Annals of Botany 104(3):359-364

Huang CL. (2014). Deciphering mycorrhizal fungi in cultivated Phalaenopsis microbiome with next-generation sequencing of multiple barcodes. Fungal Diversity 66(1):77-88
Nuraini, Hamidin, Rizky WH. (2011). Growth and development of Dendrobium spectabile orchid protocrom to various combination alternative media in vitro. Prosiding Seminar Nasional Florikultura. 1-10

Rasmussen NH \& Rasmussen FN. (2007). Trophic relationships in orchid mycorrhiza- Diversity and implication for conservation. Lankesteriana 7(1-2):334-341

Rasmussen HN \& Rasmussen FN. (2009). Orchid mycorrhiza: implications of a mycophagus life style. Oikos 118(3):334-345

Reddy J. (2019). Nutrient media used for micropropagation of orchids: a research review. World Journal of Pharmaceutical Research 5(9):1719-1732

Tantasawat PA, Khairum A, Arsakit K, Poolsawat O, Pornbungkerd P, \& Kativat C. (2015). Effects of different culture media on growth and proliferation of Dendrodium Earsakul protocorm-like bodies. Hort. Technology 25(5):681-686

Yam TW \& Arditti J. (2009). History of orchid propagation: a mirror of the history of biotechnology. Plant Biotechnology Reports 3(1):1-56

Zahara M, Datta A, Boonkorkaew P, \& Mishra A. (2017). The effects of different media, sucrose concentrations and natural additives on plantlet growth of Phalaenopsis Hybrid 'Pink'. Braz. arch. biol. technol. Vol. 60 May 11.

Zhang, Shi-Bao \& Yang, Ying-Jie \& Jia-Wei, Li \& Qin, Jiao \& Zhang, Wei \& Huang, Wei \& $\mathrm{Hu}$, Hong. (2018). Physiological Diversity of Orchids. Plant Diversity. 40. 10.1016/j.pld.2018.06.003. 